Pedrini. A.G.; Brotto, D.S.; Pimentel, D.S.; Behrends, E.; Moraes, A.A.J.

\title{
Transformative and Emancipatory Environmental Education by Marine Ecotourism in the Marine Environmental Protection Area of Armação dos Búzios (RJ, Brazil)
}

\author{
Educação Ambiental Transformadora e Emancipatória pelo \\ Ecoturismo Marinho em Área de Proteção Ambiental \\ Marinha de Armação dos Búzios (RJ)
}

\author{
Alexandre de Gusmão Pedrini, Daniel Shimada Brotto, Douglas de Souza Pimentel, \\ Eric Behrends, Alenne Alves Junqueira de Moraes
}

\section{ABSTRACT}

The Management of Marine Protected Areas (MMPA) has been a complex task in Brazil. Transformative and Emancipatory Environmental Education (TEEE) inspired on Paulo Freire's ideas should be based primarily on individual and collective political and financial independence. The Marine Ecotourism (ME) could make the MMPA at Marine Protected Area of Armação de Búzios (MPAAB) with the aid of TEEE. Ecoturismar project tested the hypothesis that ME would provide a feasible proposal for MPAAB. The sample consisted on 85 persons present at the area during the summer season, as also local residents. The methodology and the main results were: a) Identification of the main stakeholders involved in the tourism chain of the municipality to establish partnerships; b) Obtaining the approval and support of local authorities; c) Getting sponsorship for accommodation and food; d) Contact with local security, touristic and environmental authorities; e) Route selection on rocky shore to develop the underwater interpretive trail between the beaches of João Fernandes and João Fernandinho; f) Taxonomic survey of marine biodiversity; g) Elaboration of a contextualized poster; $h$ ) Selection of attractive biological species; i) Formulation of four dialogical and interpretative lectures; j) Formulation of interpretative cards with photographs of local biodiversity; k) Elaboration of support rafts with plastic bottles and other materials. The evaluation of the marine trail as an ecotouristic product was done by the confrontation of pre / pos tests. On the beach, the tourists filled a form with their data, authorized the test and answered a pre-test. Before that, they received an interpretative lecture on local marine biota. At the end of the trail, they responded to the post-test. The evaluation of tourist perceptions presented: a) Significant increase in the perception of the environment on an holistic approach; b) Increase in the perception of social and environmental interactions in relation to the marine ecosystem; c) Increase in the perception of negative effects of conventional marine tourism on the environment and marine organisms. The hypothesis that the TEEE could be developed through a product of ME by aims of underwater trails in protected areas was approved. The ME can be implemented in MPAAB replacing the current massive, excluding and predatory forms of tourism.

KEYWORDS: Sustainability; Environmental Awareness; Ecotourism Products; Marine Trails; Education. 


\section{RESUMO}

A Gestão de Áreas Protegidas Marinhas (GAPM) tem sido tarefa complexa no Brasil. A Educação Ambiental Transformadora e Emancipatória (EATE), de inspiração freiriana, baseia-se prioritariamente na independência política e financeira do cidadão. A GAPM na Área de Proteção Ambiental Marinha de Armação dos Búzios (APAMAB) poderia ser mais efetiva com a EATE pelo ecoturismo marinho (EM). $O$ projeto Ecoturismar testou a hipótese de que o EM seria uma proposta viável para a APAMAB. Os sujeitos estudados foram 85 cidadãos presentes a área na época de verão e os moradores locais. A metodologia e seus resultados principais foram: a) seleção de uma área com costões rochosos marinhos; b) Identificação dos principais atores sociais envolvidos na cadeia turística do município para estabelecer parcerias; c) contato com as autoridades municipais de segurança, turismo e meio ambiente, obtendo autorização de pesquisa local e apoio no mar; d) parceria com Pousadas Ville La Plage/La Foret que concedeu estadia e alimentação; e) seleção do percurso em costão rochoso para a trilha interpretativa submarina entre as praias de João Fernandes e João Fernandinho; f) levantamento taxonômico da biodiversidade marinha; g) formulação de pôster de uma teia trófica contextualizada com os organismos locais; h) seleção de espécies biológicas para atrativos ecoturísticos; i) produção de quatro preleções interpretativas dialógicas e problematizadoras; j) formulação de fichas interpretativas com fotografias da biodiversidade local; k) confecção de balsa com garrafas pet e rede de plástico para levar equipamentos na trilha e descanso. A avaliação dos ecoturistas foi através da confrontação de pré/pós testes. No início da trilha, ainda na areia da praia, o ecoturista preencheu dados de sua caracterização, autorizou o teste, respondeu ao pré-teste e recebeu uma preleção interpretativa. Na trilha submarina conheceu a biodiversidade marinha e recebeu preleções dialógicas problematizadoras em três áreas interpretativas. Fora da água respondeu ao pós-teste e fez a avaliação do produto. O ecoturista registrou: a) aumento significativo no principal indicador de mudança de percepção de que o ambiente é o todo; b) incremento no número de interações entre os componentes do ecossistema marinho; c) aumento na percepção de que o turismo marinho aumenta os efeitos negativos sobre o mar e seus organismos. A capacitação em EM ocorreu como uma disciplina no curso para guias de turismo do Ministério do Turismo para moradores locais. Fica aprovada a hipótese de que a EATE poderia ser desenvolvida através de um produto de EM por trilhas subaquáticas em áreas protegidas.

PALAVRAS-CHAVE: Sustentabilidade; Unidade de Conservação; Ecoturismo Marinho; Trilha Subaquática; Educação Ambiental.

\section{Introduction}

Tourism has been presented by public policies as an effective strategy to generate and distribute wealth for a long time, (BRASIL 2002, 2006 a, b, 2007, 2008, $2010 \mathrm{a}, \mathrm{b}, \mathrm{c}$ ). However, Tosun (2000) presents obstacles for the practice of traditional tourism by the absence of appropriate legal basis, adequately trained professionals; few mechanisms allowing popular participation; means to prevent the manipulation of local communities by people that did not represent them, encouragement and financial support for small entrepreneurs. In fact, this occurs in many developing countries like Brazil. 
The environmentally and socially sustainable ecotourism opposes to the massive and restrictive tourism. According to Fennel (1999) ecotourism generated in the nineties about 10-17 billion dollars worldwide, proving that the activity can generate economic development. Specifically for marine ecotourism (ME), no data were reported, however it is understood as a sustainable industry, presumed to be held by thousands of people, mainly in Atlantic Europe. Garrod et al (2002) and Garrod and Wilson (2004) argue that the ME has enormous potential as one of the suitable strategies for coastal environmental management and rational environmental development. Indeed, ME are getting more attention from scientists from the 21st century (GARROD et al, 2002; 2003, CATER, 2003; ORAMS, 2003; PEDRINI et al, 2011; RHORMENS, 2014; RHORMENS; PEDRINI, 2015; PEDRINI et al, 2016).In Brazil, the $E E$ is a main conceptual and operational assumption that characterize terrestrial and marine ecotourism (MENDONÇA; NEIMAN, 2005; PEDRINI et al. 2011). Saito et al. (2014) stated that EE based on Paulo Freire's ideas should be a continuously practice in any community and, in this case, for the development of a ME product, should comprises every person involved in touristic activities in the region, from entrepreneurs to guides. In the case of marine ecotourism, environmental interpretation (EI) is also considered as a specific practice addressed to clients of ecotourism products (GARROD et al. 2002; MADIN; FENTON, 2004). In relation to the use of trails as ecoturistic products, they consist in a short duration product, which makes them more suitable for the practice of EI (MARASCHIN; PEDRINI, 2003; OLIVEIRA et al, 2007; PEDRINI; MERIANO, 2007; RHORMENS; PEDRINI, 2015; PEDRINI et al, 2016).

The tourist presence in any region, in fact, is temporary and more frequently they only seek fun and not learning in the ecotourism products, but if their stay at this region exceeds the time required for a trail, EE practices could be adopted. Thus, it is understood that the residents are the primary target audience of TEEE practices, promoted to implement the ME products, here understood as commercial activities operated by those residents. Thus the unsustainable actions and attitudes of residents and visitors, would be, certainly, replaced by sustainable ones, enabling a livelihood and a sustainable tourism product (FORRESTELL, 1993; CATER, 2003; GARROD; WILSON, 2004; PEDRINI et al., 2011; 2016; RHORMENS; PEDRINI, 2015).

To provide society a new ME product requires the prior assessment of their effectiveness, which can be measured by the assimilation of new concepts or for correcting erroneous or missing attitudes. Thus, some specific and essential contents on this subject are briefly explained below.

\section{THEORETICAL BACKGROUND}

\section{Emblematic key concepts}

A concept is an elementary part of a theory; it is a mental construct or abstraction defined socially about a certain objective reality. The concept is the basis of thought and communication between human beings, according to Veal (2011). Concepts can also be evaluated by scientific methodology, in specific contexts or realities, in this case, key concept is understood as a parameter for evaluation and its meaning must be objectively defined. The throughout understanding of a concept can change radically a preliminary situation (pre-test) by a new one (post-test). This 
kind of approach in EE researches has achieved many contributions, when evaluating the effect of EE practices in specific audiences (PEDRINI et al, 2013; 2016).

\section{Transformative and Emancipatory Environmental Education (TEEE)}

TEEE inspired on Paulo Freire's ideas (Saito et al., 2014) coupled with ecotourism could be understood as a valuable choice addressing sustainable income generation in protected areas, replacing predatory and deleterious practices, as also reducing negative impacts of human presence in these areas. However, little is known about the pedagogical efficacy of practices based on these ideas (PEDRINI, 2007a, b). Generally, in Brazil and mainly in Rio de Janeiro, neither EE nor El are practiced at the so-called ecotourism products more frequently presented to tourists, and it is a worrisome situation, because both, EE and El, are essential assumptions and guidelines for any activity intended to be classified as real ecotourism. (PIRES, 2005).

The EE approach here proposed (TEEE) relies primarily on financial and political independence of the individual, as also of the whole community, this feature suits well when coupled to Marine Ecotourism (ME), seeking to change unsustainable attitudes (PEDRINI et al., 2011) present in many localities of the Brazilian coast (PEDRINI et al., 2013). Thus, TEEE was elected as a suitable model for the development of the marine ecotourism product focused in this paper (PEDRINI et al., 2011).

\section{Ecotourism and marine tourism features}

There are conceptual mistakes on what is meant by EE and ecotourism and these mistakes allows unscrupulous entrepreneurs and wild capitalists to offer products that are not true ecotourism. In this case, they offer only the marine tourism (MT). At Table 1 where presented specific features that, differentiate marine ecotourism (ME) from simple marine tourism (MT). It is clearly shown that the ME are opposed in many respects to MT, due to its features that aims social and environmental sustainability, as well as the environmental interpretation and education focused on the tourists.

Table 1: Specific conceptual features of ecotourism and marine tourism.

Source: adapted from Pedrini et al. (2011).

Quadro 1: Características conceituais específicas do ecoturismo e do turismo marinho

Fonte: adaptado de Pedrini et al. (2011).

\begin{tabular}{|l|c|c|}
\hline \multirow{2}{*}{\multicolumn{1}{|c|}{ Features }} & \multicolumn{2}{c|}{ Conceptual attributes } \\
\cline { 2 - 3 } & Marine ecotourism & Marine tourism \\
\hline Goals & Gain + sustainability & Gain \\
\hline Group size & Environmentally Limited & Economically limited \\
\hline Communitarian involvement & Present & Absent \\
\hline El and EE & Present & Absent \\
\hline Negative impacts & Considered and reduced & Scarcely considered \\
\hline Regional income generation & Present & Optional \\
\hline Regional tax generation & Present & Present \\
\hline In situ presentation of marine biota & Present & Absent \\
\hline Interpretive briefing at specific points & Present & Absent \\
\hline
\end{tabular}


Marine ecotourism (ME) can be accomplished efficiently through an interpretive marine trail using snorkeling diving equipment or not. Thus, the local environment will present just a strait and controlled zone, exposed to tourist's impact. Thus, this issue will be questioned in the next section.

\section{Marine trails}

The ME concept adopted in this study was adapted from Pedrini et al (2011), being minimally defined as a tourism product made within the shallow seas near a shore or reef, with limited number of clients (maximum 10) being conducted over an interpretive trail, accompanied by a resident conductor. One of the major aim is the involvement of local community, in order to participate and plan the implementation of the ecotourism product. It's desirable that lodging facilities could be partners of the product. The training of trail conductor, must be made by qualified and authorized personnel, based on standards already satisfactorily adopted elsewhere.

International adoption of underwater trails is well known (HANNAK, 2008). In Europe and the Mediterranean countries, for example, underwater trails are often used for leisure, recreation and education. A great number of entities from various countries such as France, Slovenia, Greece and Italy invested an amount of approximately 2 million Euros in a detailed manual for the planning, construction and application of underwater interpretive trails. The manual is much more than guidelines for creating trails, but also explains how to use them as for pedagogical purposes (BAUD et al., 2012).

In the Brazilian context, Lima (1998) defines an interpretive trail as: a) Short path (500 to 1,000 meters) planned, demarcated and used in order to optimize the understanding of natural, cultural or build features, in a certain region; b) Used for recreational and educational purposes, as part of environmental education or psychotherapy and c) Aiming to integrate or reintegrate people to the environment. This concept extends the functions of the tracks only considered as way. However, it is noticeable that simple paths over terrestrial or aquatic natural environments have received the name "ecological trail". In addition, many, being covered without proper planning and no clear objective of increasing the environmental awareness of its passersby (LECHNER, 2006).

To ensure the real effectiveness of an ecotouristic trail, aiming environmental interpretation (EI), the following conditions must be present (adapted from Pedrini 2006): a) Situated and contextualized in a natural/built environment; b) Designed in a participatory manner involving local community in an approach resembling Paulo Freire's ideas; c) Natural assets previously surveyed, considering abiotic (geodiversity, meteorology, water resources, etc.) and biotic (biodiversity) taxonomic and ecologically characterized by aims of printed materials as banners, folders and cards; d) Permanently check and upkeep, identifying impacts and taking mitigation procedures; e) Periodical evaluation aiming its real objective, as a conservational aim integrated to ecotourism.

Pedrini et al (2013a) surveyed about the use of submerged (WEGNER, 2002) or even terrestrial (MEIRELES et al., 2013) marine trails, aiming ecotourism in Brazil, as presented in Table 2. 
Table 2: Features and purposes of marine trails described in Brazilian literature

Source: adapted from Pedrini et al. (2013).

Quadro 2: Características e propósitos das trilhas marinhas descritas na literatura brasileira

Fonte: adaptado de Pedrini et al. (2013).

\begin{tabular}{|c|c|c|c|}
\hline \multicolumn{2}{|l|}{ Features } & \multicolumn{2}{|c|}{ Purposes } \\
\hline Author & State & Pedagogical & Ecoturistic \\
\hline Wegner (2002) & \multirow{5}{*}{ Santa Catarina } & & $\mathrm{X}$ \\
\hline Wegner et al. (2004) & & & $X$ \\
\hline Bertuol (2005) & & & $\mathrm{X}$ \\
\hline Lima et al (2006) & & & $\mathrm{X}$ \\
\hline Ayrosa (2011) & & & $\mathrm{X}$ \\
\hline Berchez et al. (2005) & \multirow{7}{*}{ São Paulo } & & \\
\hline Berchez et al. (2007) & & $\mathrm{X}$ & \\
\hline São Paulo (2008) & & & $\mathrm{X}$ \\
\hline Hadel (2010) & & $\mathrm{X}$ & \\
\hline Machado et al. (2010) & & & $\mathrm{X}$ \\
\hline Pedrini et al. (2010) & & & $\mathrm{X}$ \\
\hline Lima et al. (2010) & & & $\mathrm{X}$ \\
\hline Pedrini et al. (2011) & \multirow[t]{2}{*}{ Rio de Janeiro } & & $\mathrm{X}$ \\
\hline Meireles et al. (2013) & & $X$ & \\
\hline Barbosa and Perinotto $(2010)^{*}$ & Piauí & & $\bar{X}$ \\
\hline Rhormens (2014) & Bahia & & $\mathrm{X}$ \\
\hline Total $=16$ & & 4 & 12 \\
\hline
\end{tabular}

${ }^{*}$ This trail is on an estuary and is done on foot, even in the water, being different from the characterization of underwater trail where the subject goes through submerged in the water; but their inclusion was accepted in this picture until this conceptual limit be better defined.

The above exposed show that the majority $(75 \%)$ of the listed trails, present ecotouristic purposes and that they are mainly located at the southeast coast of Brazil. at São Paulo (44\%) and Santa Catarina (31\%). Mainly because of the welldeveloped touristic industry and Strong economy of these states. However 15 are the above mentioned trails, just the ones from São Paulo state are presently in use, as they are sponsored and maintained by the São Paulo University (USP), presenting mainly a pedagogical approach, being a permanent part of EE projects, TrilhaSub (BERCHEZ et al., 2005, 2007) and Centro de Biologia Marinha (HADEL, 2010). Marine trails are surely a useful expedient for Marine ecotourism aiming social emancipation according to Paulo Freire's ideology (PEDRINI et al., 2011).

\section{Preliminary achievements}

Aiming a better understanding of ECOTURISMAR project, the main results of six preliminary projects will be briefly described bellow, these results show the urgency of actions to mitigate the consequences of conventional marine tourism activities, aiming to integrate these activities to the environment where they are developed. It is emphasized that the chronological sequence given, follows the development of the studies and not to the publication of their results.

In the first study, Pedrini et al. (2013) evaluated the environmental perception by people interested in the implementation of marine ecotourism in Búzios, highlighting the findings that most of the respondents expressed the integrative concept of environment as defined in Reigota (2007). It was also reported that residents from inland regions expressed this concept with more often than those from 
seaside regions. Additionally it was seen that the majority did not conceptualized the marine environment correctly.

In a second study, Pedrini et al. (2015) evaluated the perceptions about environmental education (EE) and ecotourism from the same public focused in the above-mentioned study, registering that most of them understand EE as related mostly to environmental conservation and public awareness, they do not view the full potential of EE as proposed by Pedrini (2007a). Surprisingly, the concept of ecotourism proved to be poorly understood by the respondents, although many of them are tourism professionals.

In the third study, Pedrini et al. (2011) presented results of a survey aiming to characterize the main tourism entrepreneurs and related persons from Armação dos Buzios, aiming to identify partners from the business sector, citizens and government. In this study it was also presented the selection criteria for site selection for the implementation of a marine trail, according to its attractive points; characterizing the relevant biotic and abiotic aspects; characterizing the contextualized ecosystem, and finally, the outline of the general methodology.

In the fourth study, Pedrini et al. (2012b) presented an inventory of benthic flora along the selected stretch for the marine trail in João Fernandes Beach, it was justified for the scarcity of works at the region and the fact that marine flora consists in a very relevant and aesthetically appeal at the marine trail. Sampling occurred from December 2009 to January 2012. A total of 64 taxa were identified, including a new occurrence of Dictyopteris polypodioides for the state of Rio de Janeiro, as also Halymenia elongata and Laurencia dendroidea, both, new references at Rio de Janeiro upwelling region, it was perceived that the flora found is similar to the aforementioned at nearby beaches.

In the fifth study, Pedrini et al. (2012) presented the results of the evaluation of a training course for touristic guides, held with the support of local entrepreneurs and authorities. The event was named "Environmental Education for Marine Tourism Course" (I CEAM), being offered to municipal employees at education, environment and tourism offices from coastal municipalities of the state of Rio de Janeiro. The aim was to present the marine ecotourism as a sustainable alternative for tourism at Rio de Janeiro seashore. The course evaluation showed that the attending public achieved good results, however, few of them were able to perceive the connections between marine environment and society; something achieved just by an extensive approach. Generally, the course consisted in a preliminary test of the ecotouristic product, demonstrating its viability, effectiveness and weaknesses. The same course was offered a second time, to a specific public composed of tourism professionals from Armação dos Búzios and neighbor cities, whose evaluation is still in development process, although preliminary results show the effectiveness of these kind of approach.

Thus, this article presents the results of the evaluation of preliminary and posterior environmental perceptions from tourists that experienced an especific ecotouristic product, before it was reconfigured according to the above reported results. The main goal was to present marine trails as a viable alternative product for the local tourism dealers from the community, according to the Transformative and Emancipatory Environmental Education concept (FREIRE, 1996; SAITO et al, 2014). 


\section{Studied area}

The natural attractions of Armação dos Búzios, in the state of Rio de Janeiro, are its beaches that made it one of the most important tourist destinations in South America. Along its beaches, rocky shores and islands, rich reef environments could be found, teaming of organisms like invertebrates, fish, sea turtles and cetaceans, contributing to the uniqueness of this stretch of the Brazilian coast, unfortunately, this peculiarity has been collaborating for its degradation by intense and predatory tourism. The research from Oigman-Pszczol and Creed (2007) in the region, attributed most of the marine debris found to beach goers (tourists or not) and suggest that the municipal government has not been effective on adopting actions in order to solve this situation.

Armação dos Buzios received about 1.500 .000 visitors in 2009 (cf. SETUC/Búzios, 2011) most of them come in the travel ships that stay at the coast from 3 to 7 days. These tourists bring little contribution to local economy, as they come to shore mainly for souvenirs and are not interested on sociocultural aspects of local community or natural environment as stated Pedrini et al (2011). Castro (2011) raised the issue about negative tourism impacts related to travel ships, mainly as consequence of the inadequacy of municipal services to attend to the large amount of people.

The Municipal act $\mathrm{n}^{\circ} 135$ from November, 6, 2009 established the Marine Protected Area of Armação de Búzios (MPAAB) along the whole municipal seashore (Figure 1). It was also established the Natural Coral Park in this area. However, it is doubtful if citizens or visitors know about these protected areas.

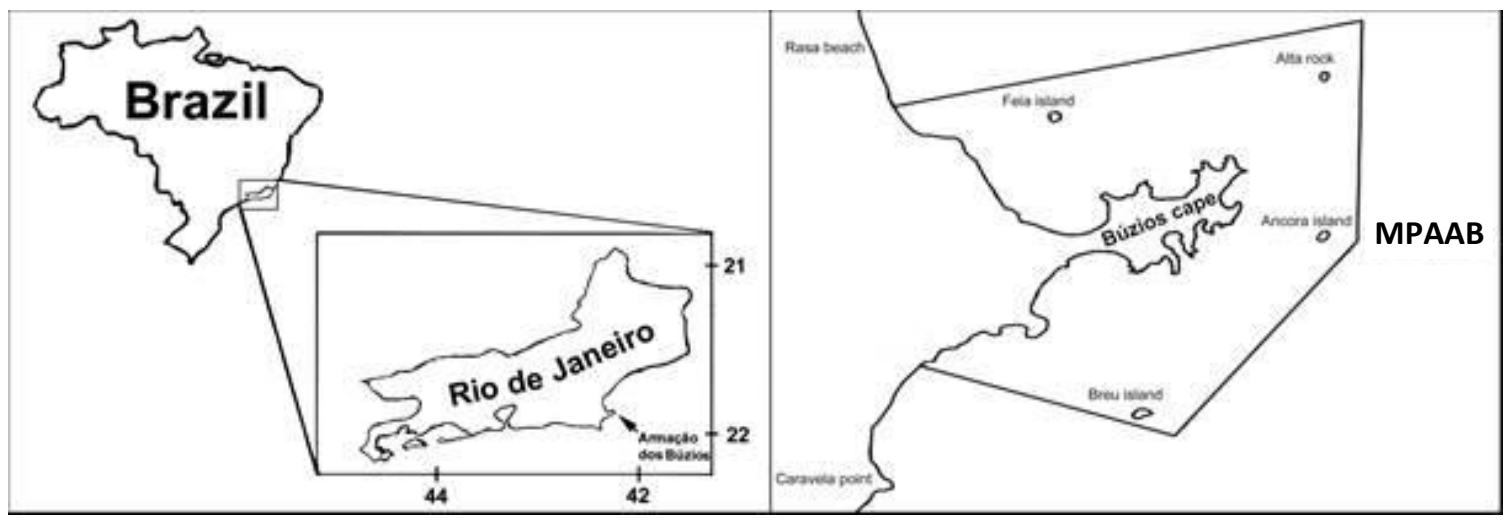

Figure 1: location of Armação de Búzios (left) and limits of MPAAB (right).

Figura 1: localização de Armação de Búzios (esquerda) e limites da MPAAB (direita).

The Marine Protected Area of Armação de Búzios (MPAAB), was chosen for the development of this work as it's included in a region victimized by the predatory and excluding tourism (SALES and ANTONIO FILHO, 2008), creating the need for new approaches and touristic products in order to generate social welfare in a sustainable manner (BARBOSA, 2003). 


\section{Methodology}

The evaluation of the pedagogical effectiveness of the Ecotourism product is the main aim of this study. The marine trail has been based in the original idea proposed by Pedrini et al (2011). So, an underwater trail was designed and demarcated along rocky shores located between the beaches of João Fernandes and João Fernandinho (MPAAB), at $22^{\circ} 44$ '25, 63 'South and $41^{\circ} 52^{\prime} 29.39$ " West, being located on the extremity of the cape of Búzios. According to the preliminary geomorphological and marine biota surveys (PEDRINI et al. 2011; 2012a), three interpretive points along the trail were set as shown at Figure 2.

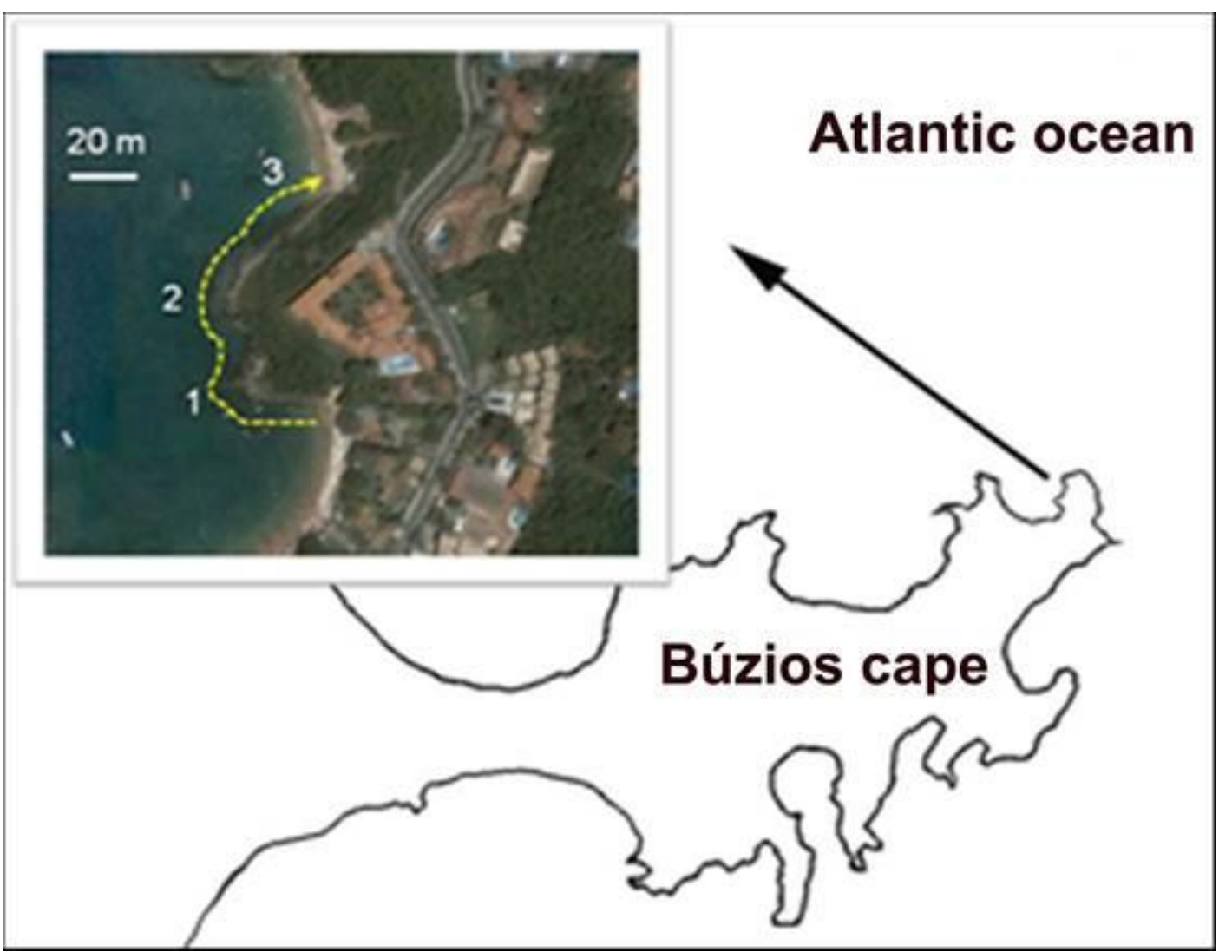

Figure 2: Location of the stretch between the beaches of João Fernandes and João Fernandinho, highlighting the route designed for the marine trail and the interpretive points

Source: based on Google Earth imagery.

Figura 2: Localização do trecho entre as praias de João Fernando e João Fernandinho, com destaque para o percurso concebido para a trilha marinha e os pontos interpretativos.

Fonte: com base em imagens do Google Earth.

A briefing at the beach, featured the Ecoturismar as a tourist product, for groups of up to five people, with the aid of an explanatory banner, followed by stretching and presentations and the traverse of the trail by "snorkeling", aided by a raft and interpretive cards. Along the path, the aspects of marine ecosystems and human impacts were described at defined interpretative points. The above-mentioned procedure was adapted from a model already tested and implemented in the State Park of the Anchieta Island in Ubatuba - SP as described by Pedrini et al. (2008). So, the here described ecotouristic product, was inspired by the pedagogical model of Berchez et al. (2007) studied and reconfigured in later works of Pedrini et al. (2007 $\left.2008^{a}, 2008^{b}, 2010 b\right)$. This model was the basis for the marine ecotourism product named "Promar", developed and adapted by Rhormens (2014), methodological 
differences between Ecoturismar and Promar model have been specified in Pedrini et al. (2016).

Some aspects of developed activities were presented next (figure 3), additionally, short videos were made aiming to register aspects of these activities and local natural aspects along the marine trail, these videos were available at a youtube channel (https://www.youtube.com/channel/UCs8K6pMWgSzw2O zetUmotw).
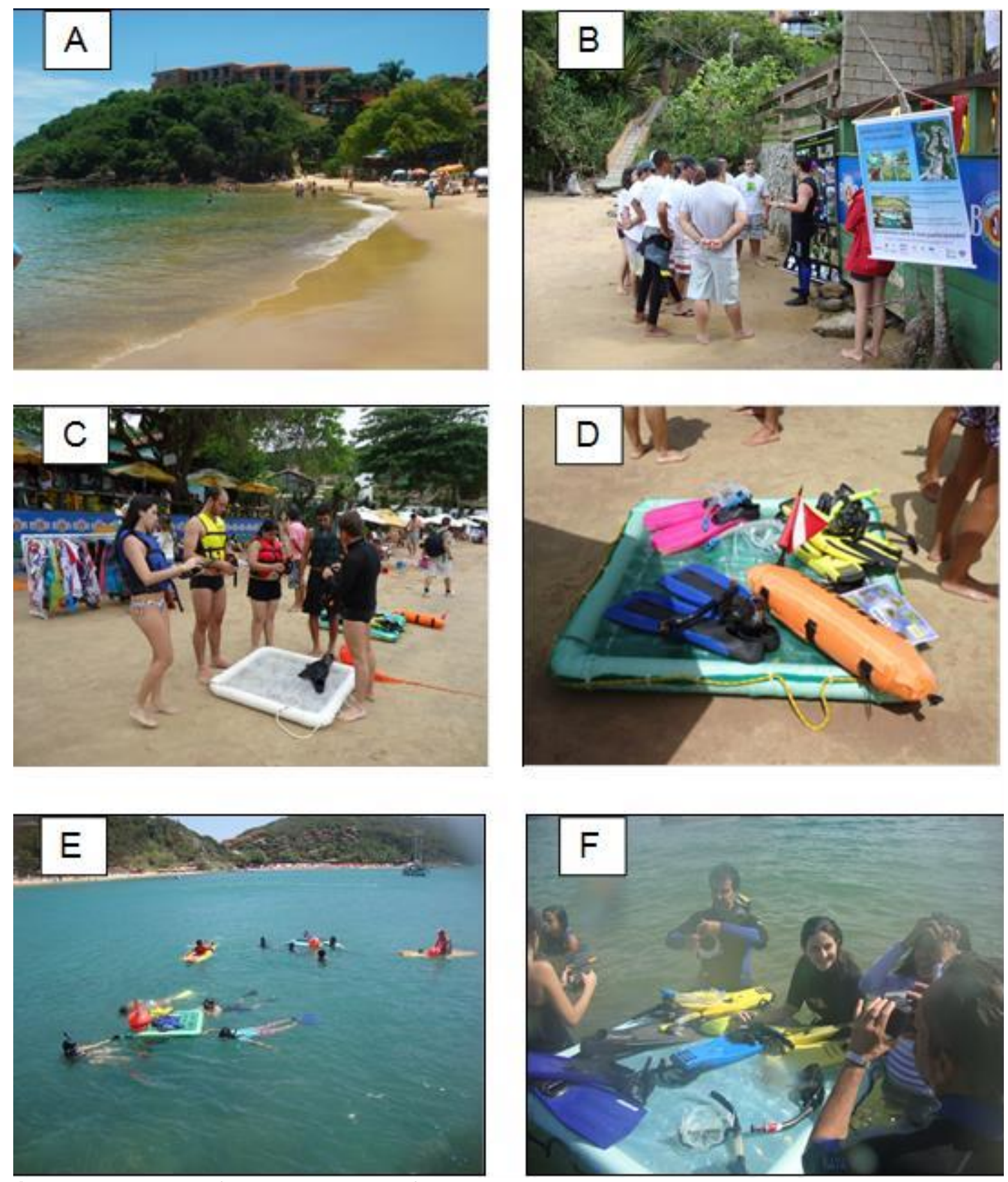

Figure 3: Aspects of the chosen area for the project in João Fernandes beach at Armação dos Búzios - RJ (A), briefing in the beach by aim of a poster (B), group preparing for the marine trail (C), safety equipment used $(D)$, two groups traversing the trail $(E)$ and group chatting after the trail $(F)$.

Figura 3: Aspectos da área escolhida para o projeto na Praia de João Fernandes em Armação dos Búzios - RJ (A); Briefing na praia por meio de um cartaz (B); Grupo prepara-se para a trilha marinha (C); Equipamentos de segurança utilizados (D); Dois grupos percorrendo a trilha (E) e Grupo conversando após a trilha $(\mathrm{F})$. 
Activities related to the testing of the ecotouristic product occurred in summers 2010 and 2012. The environmental perceptions of 85 tourists, before and after traversing the trail were evaluated. Aiming this goal, before the lecture and the end of the trail, all tourists responded to individual structured interviews (Appendix 1). The interviews sought to register the profile of the respondents (gender, age, origin and education), as also environmental knowledge and awareness. For the answers that demanded content analysis, it was followed the method explained by Bardin (1979). These responses were considered here as indicators for evaluating tourist's perception, that were explained by their profile data and the experience provided by the trail.

The answers given to explain the marine food chain and the importance of macroalgae, were categorized as satisfactory, partially satisfactory and unsatisfactory, considering as satisfactory, respectively, the answers that minimally identified marine trophic chain as the succession of related trophic levels. To evaluate the responses about the importance of the macroalgae, it was considered fully correct the one where were presented at least three valid aspects of social and ecological role of macroalgae. The responses explaining the concept of environment were evaluated according to the categories presented by Reigota (2007). The numbers of cited elements evaluated the knowledge about marine organisms and negative effects of tourism at the region of the trail. The perception of self integration with the marine environment was evaluated by the number of links in the web of life made by each respondent.

Data on each questionnaire were stored in digital spreadsheet aiming to draw diagrams that could present the variation of the perception data according to profile data before and after traversing the marine trail. To verify the significance of identified variations, paired Student's T-test and Kruskal Wallis were performed using the Statsoft inc. package. The main goal was to evaluate the presumed increases of environmental knowledge and awareness by comparing the answers given, as performed by Pedrini et al. (2009), the results were attributed to the effect of the trail and the profile data of the respondents. Negative effects of tourism and number of links in the "web of life" of Pedrini and De-Paula (2008) and percentage rate for the categories assigned to the answers concerning the importance of macroalgae and marine trophic chain knowledge.

Data for each questionnaire were stored in a single electronic spreadsheet to work out the average frequency distribution diagrams for the number of marine organisms quotes present at the trail area. It aimed to estimate the effectiveness of the product, focusing the cross-indicator comparison of performance indicators specified above as conducted in Pedrini et al. (2009), with the results attached to the trail outcome together with parameters of the respondents' profile. To verify the significance of the differences were performed paired t-test and Kruskal Wallis through the Statistica Statistical Package, in order to evaluate the increase in knowledge and environmental perception of the respondents

\section{Results}

Generally speaking about the results, the assimilation of new ideas as also changes in tourist perceptions occurred, as expressed by the comparison of preliminary (PRE) x posterior (POS) evaluations. However, the better understanding 
of the key concepts and awareness, occurred differently according to intrinsic individual factors of the tourists $(n=85)$ who traversed the marine trail.

Regardless the above-mentioned increase, it was not found significant (paired t-test, $p<0.01$ ) increase in the knowledge about local marine biota as also about negative effects of tourism. Nevertheless, significant increase (paired t-test, $p<0.01$ ) occurred in the number of links in the web of life after the trail (Figure 4).

Unexpectedly, there were no significant increase $(\mathrm{KW}, p<0.05)$ for the number of satisfactory answers about the importance of macro algae and the knowledge of the marine food chain (Figure 4).
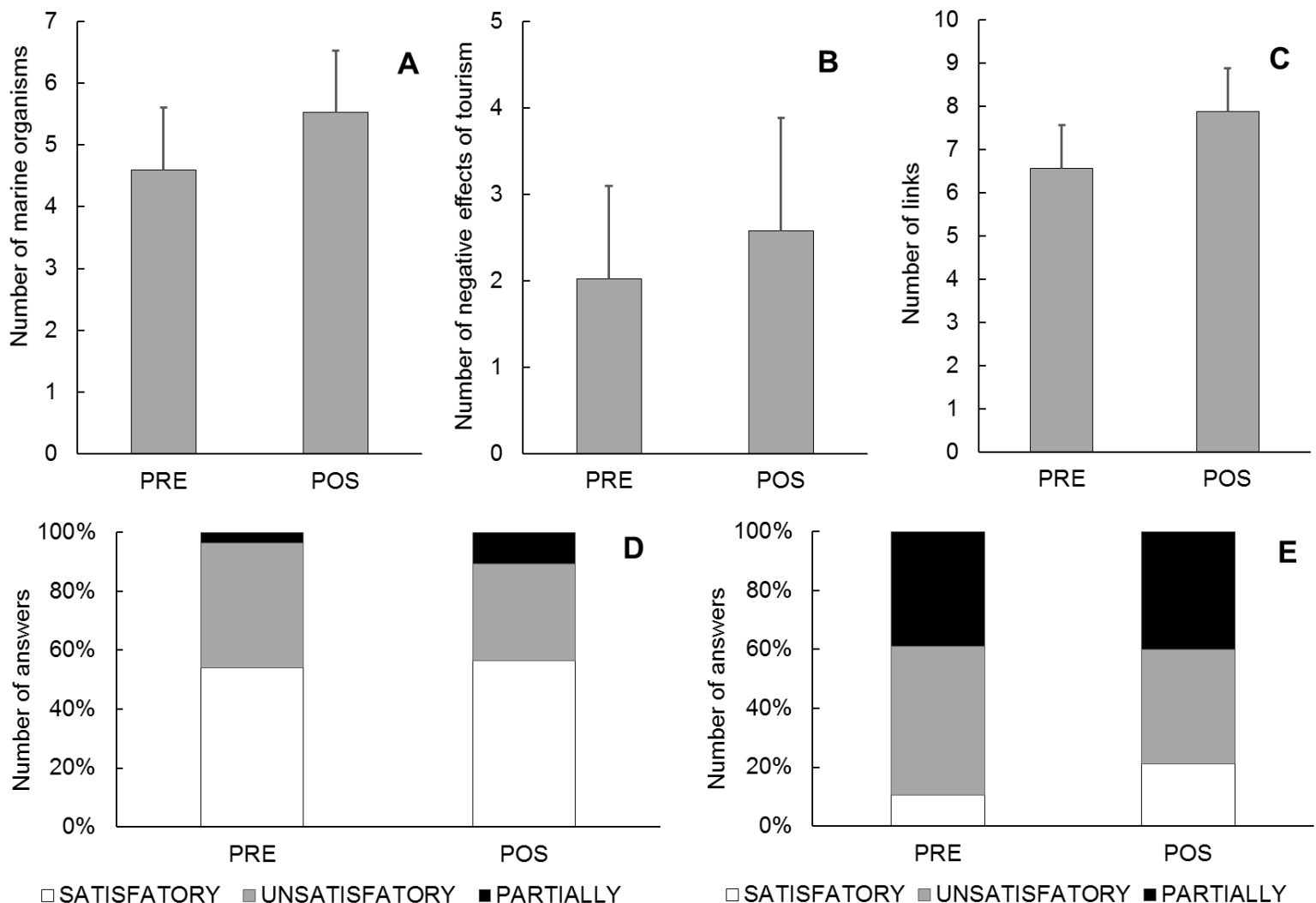

口SATISFATORY $\square$ UNSATISFATORY $\square$ PARTIALLY

Figure 4: Number (mean + standard deviation) of cited marine organisms $(A)$, negative effects of tourism (B) and links in the web of life (C); number (percentage) of satisfactory, unsatisfactory and partially satisfactory answers for the understanding of the importance of macroalgae (D) and marine food chain (E), in pre and pos test.

Figura 4: Número (média + desvio padrão) de organismos marinhos citados $(A)$, efeitos negativos do turismo (B) e elos da teia da vida (C); número (percentagem) de respostas satisfatórias, insatisfatórios e parcialmente satisfatórios para a compreensão da importância de macroalgas (D) e marinha cadeia alimentar $(\mathrm{E})$, no pré e pós teste.

The results from the analysis of the influence of respondent's profile data (age, sex, origin and education) in the increase of the knowledge and perception indicators are presented as followed.

Although, increase of all indicators at all age groups after the trail, by comparing PRE x POS evaluation was observed, but none was significant (T-paired test, $p<0.01$ ) (Figure 5). Among the evaluated age groups, there was no significant increases $(\mathrm{KW}, p<0.05)$ for the number of satisfactory answers about the importance 
of macro algae, but significant $(\mathrm{KW}, p<0.05)$ increase in the knowledge about the marine food chain was observed at the pos test for both age groups (Figure 5).
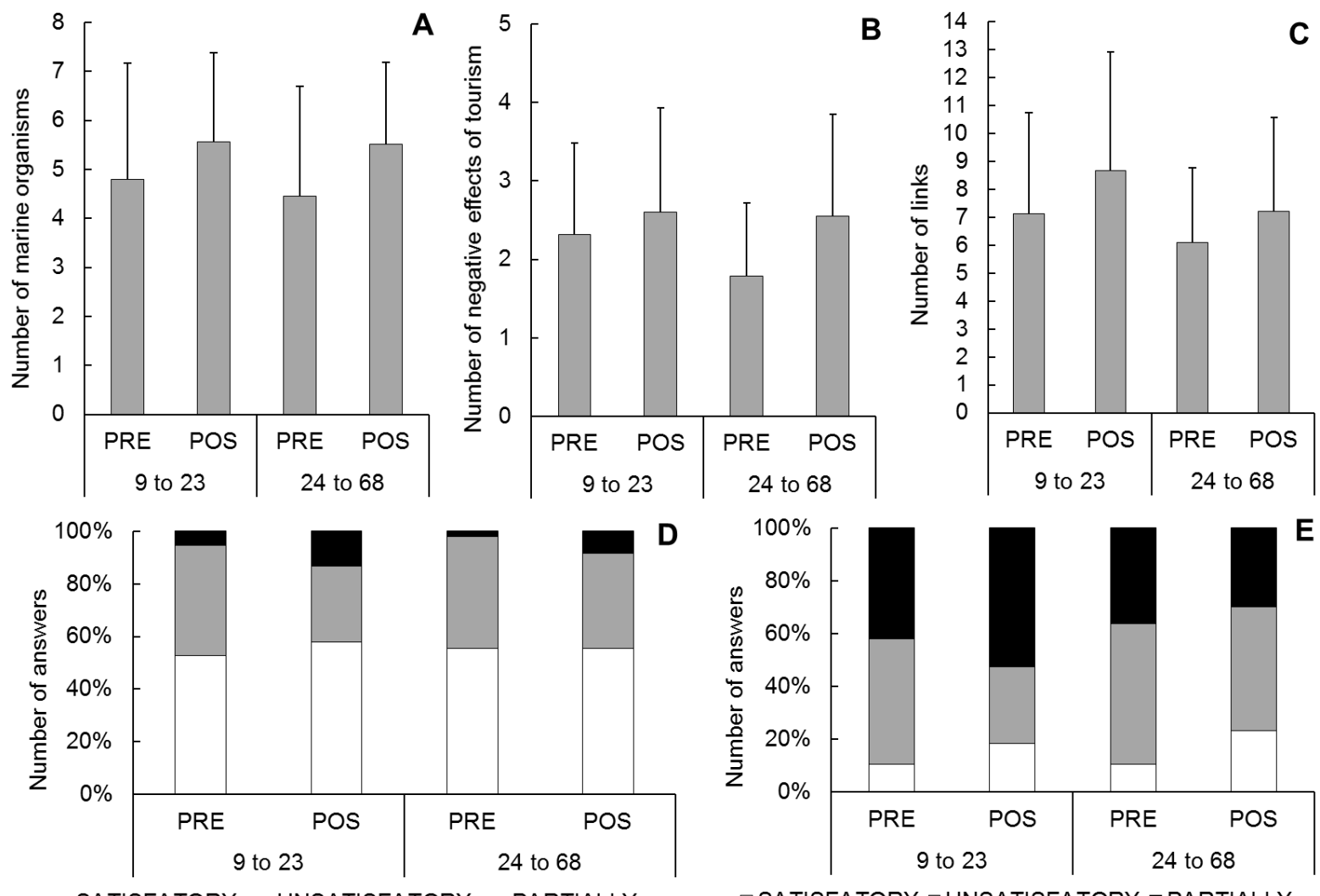

$\square$ SATISFATORY $\square$ UNSATISFATORY

$\square$ SATISFATORY $\square$ UNSATISFATORY - PARTIALLY

Figure 5: Number (mean + standard deviation) of cited marine organisms $(A)$, negative effects of tourism (B) and links in the web of life (C); number (percentage) of satisfactory, unsatisfactory and partially satisfactory answers for the understanding of the importance of macroalgae (D) and marine food chain $(E)$, in the pre and pos test according to age groups.

Figura 5: Número (média + desvio padrão) de organismos marinhos citados $(A)$, efeitos negativos do turismo (B) e elos da teia da vida (C); número (percentagem) de respostas satisfatórias, insatisfatórios e parcialmente satisfatórios para a compreensão da importância de macroalgas (D) e marinha cadeia alimentar $(\mathrm{E})$, no pré e pós teste de acordo com os grupos etários.

It was shown that the sex of the respondents does not influence the increase of the evaluated indicators, occurring small non-significant increments (paired t-test, $p>0.05$ ), from the preliminary to posterior evaluation, for all indicators in both sexes. (Figure 6).

In addition, there was no significant increase (KW, $p>0.05)$ for the number of satisfactory answers for the knowledge about the importance of macroalgae and the marine food chain. Although, both indicators above mentioned were observed that only males had partially correct answers, as they also presented fewer correct answers regarding to knowledge of the marine food chain when compared to females (Figure 6). 

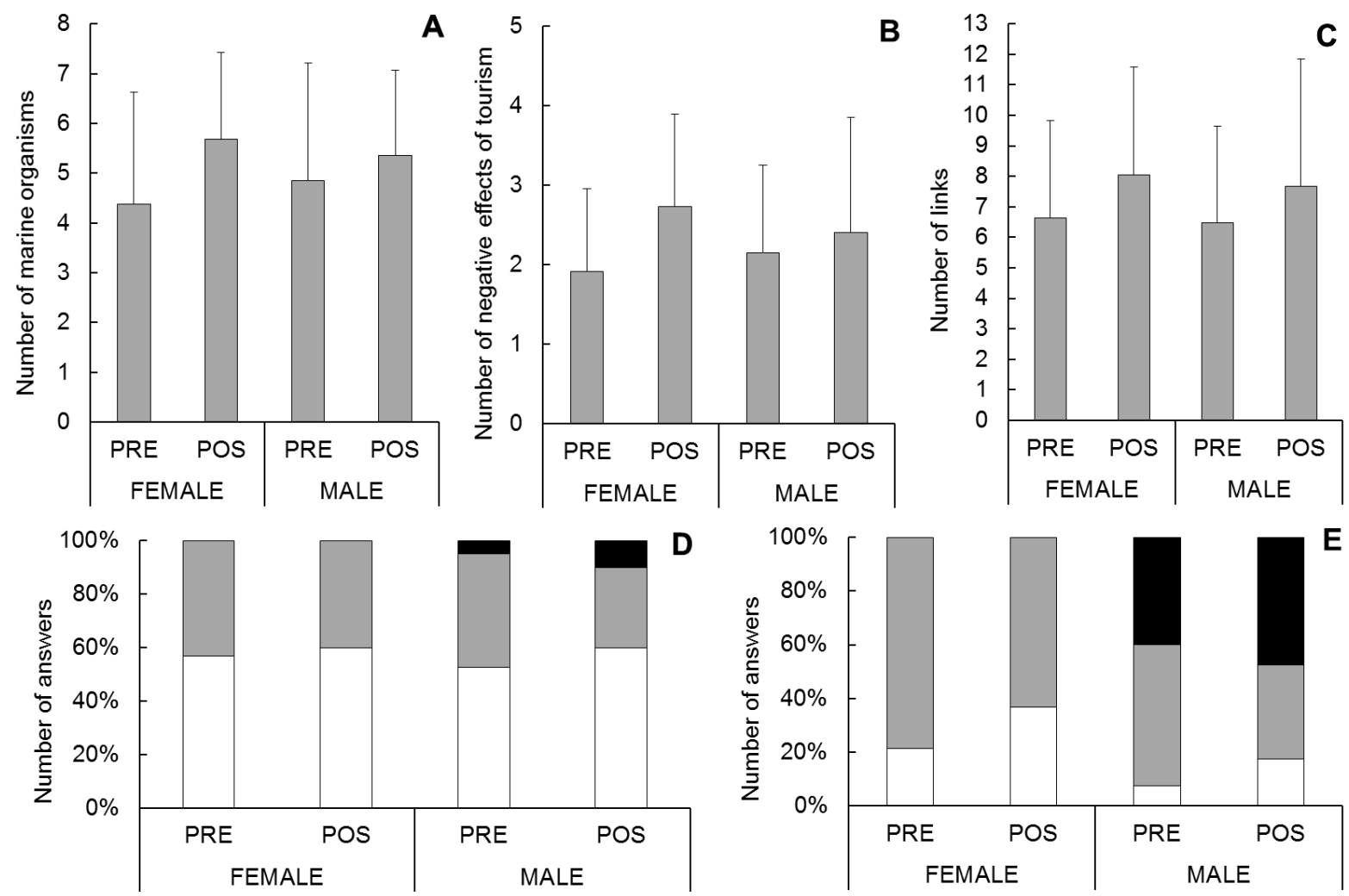

$\square$ SATISFATORY $\square$ UNSATISFATORY

-PARTIALLY

$\square$ SATISFATORY $\square$ UNSATISFATORY $\backsim$ PARTIALLY

Figure 6: Number (mean + standard deviation) of cited marine organisms (A), negative effects of tourism (B) and links in the web of life (C); number (percentage) of satisfactory, unsatisfactory and partially satisfactory answers for the understanding of the importance of macroalgae (D) and marine food chain (E), in the pre and pos test according to sex.

Figura 6: Número (média + desvio padrão) de organismos marinhos citados $(A)$, efeitos negativos

do turismo (B) e elos da teia da vida (C); número (percentagem) de respostas satisfatórias, insatisfatórios e parcialmente satisfatórios para a compreensão da importância de macroalgas (D) e da cadeia alimentar marinha (E), no pré e pós teste de acordo com o sexo.

The evaluated indicators did not vary significantly (T-paired test, $p>0.05$ ) between respondents from the inland and from the seacoast, but, significant (T-paired test, $p<0.05)$ differences were presented between their knowledge after the trail regarding the negative effects of tourism, as tourists from the inland perceived more negative effects than the ones from the seacoast (Figure 7).

After the trail, both tourists from the seacoast and from the inland did not show significant increase (KW, $p>0.05$ ) for the number of satisfactory answers about the importance of macroalgae, but to the knowledge about the marine food chain, both presented significant increase (KW, $p<0.05)$ (Figure 7). 

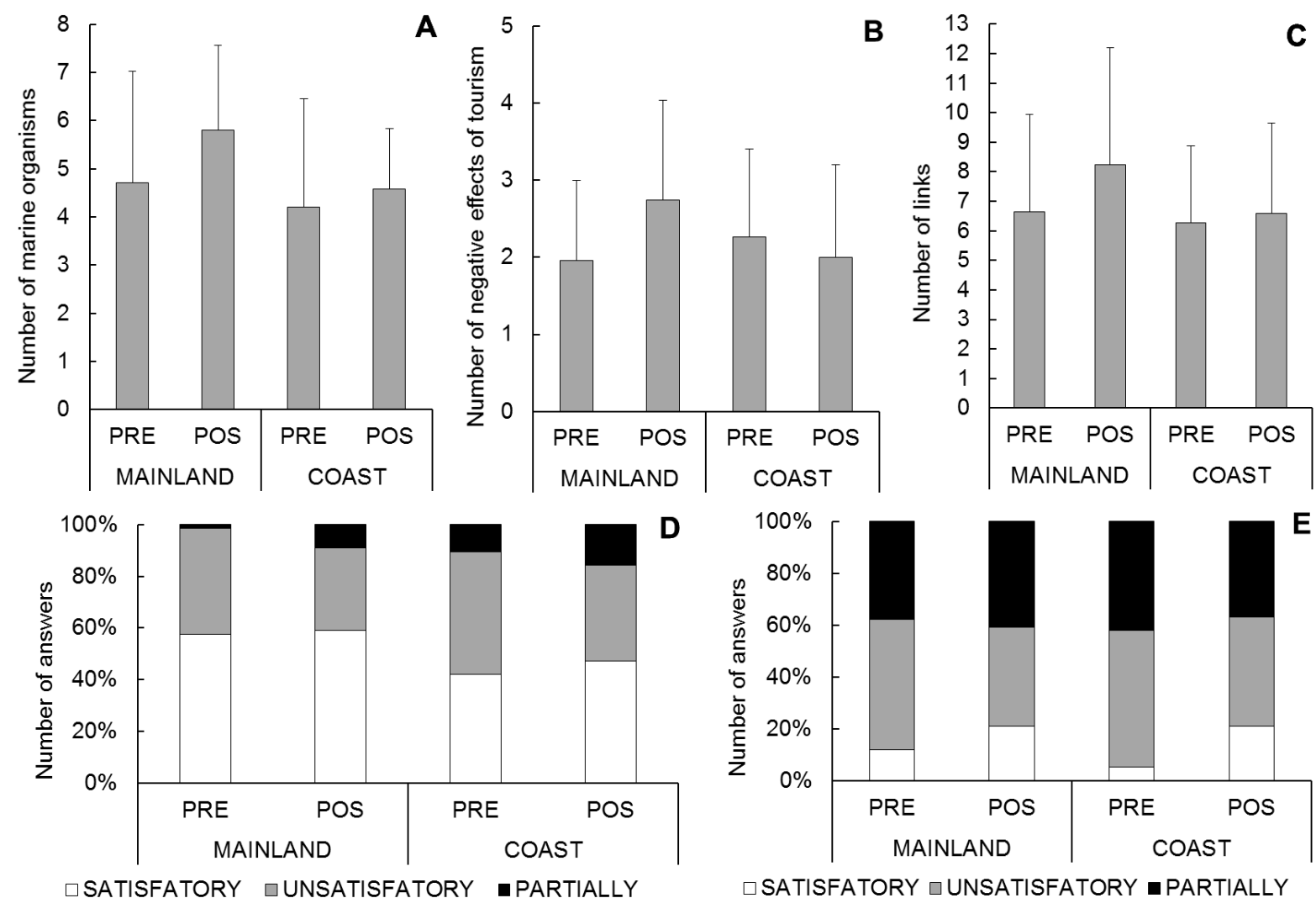

ISATISFATORY $\square$ UNSATISFATORY $\square$ PARTIALLY

Figure 7: Number (mean + standard deviation) of cited marine organisms $(A)$, negative effects of tourism (B) and links in the web of life (C); number (percentage) of satisfactory, unsatisfactory and partially satisfactory answers for the understanding of the importance of macroalgae (D) and marine food chain $(E)$, in the pre and pos test according to origin.

Figura 7: Número (média + desvio padrão) de organismos marinhos citados (A), efeitos negativos

do turismo (B) e elos da teia da vida (C); número (percentagem) de respostas satisfatórias, insatisfatórios e parcialmente satisfatórios para a compreensão da importância de macroalgas (D) e da cadeia alimentar marinha (E), no pré e pós teste de acordo com a origem.

It was observed that the education level was not related to significant (t-paired test, $p<0.01$ ) increase of the evaluated indicators, although, respondents above high school level presented significantly (t-paired test, $p<0.01$ ) higher number of connections in the web of life when compared to respondents of lesser level of education (Figure 8).

A significantly $(\mathrm{KW}, \mathrm{p}<0.05)$ better understanding about macro-algae and about marine food chain were also presented by respondents above high school level (Figure 8). 

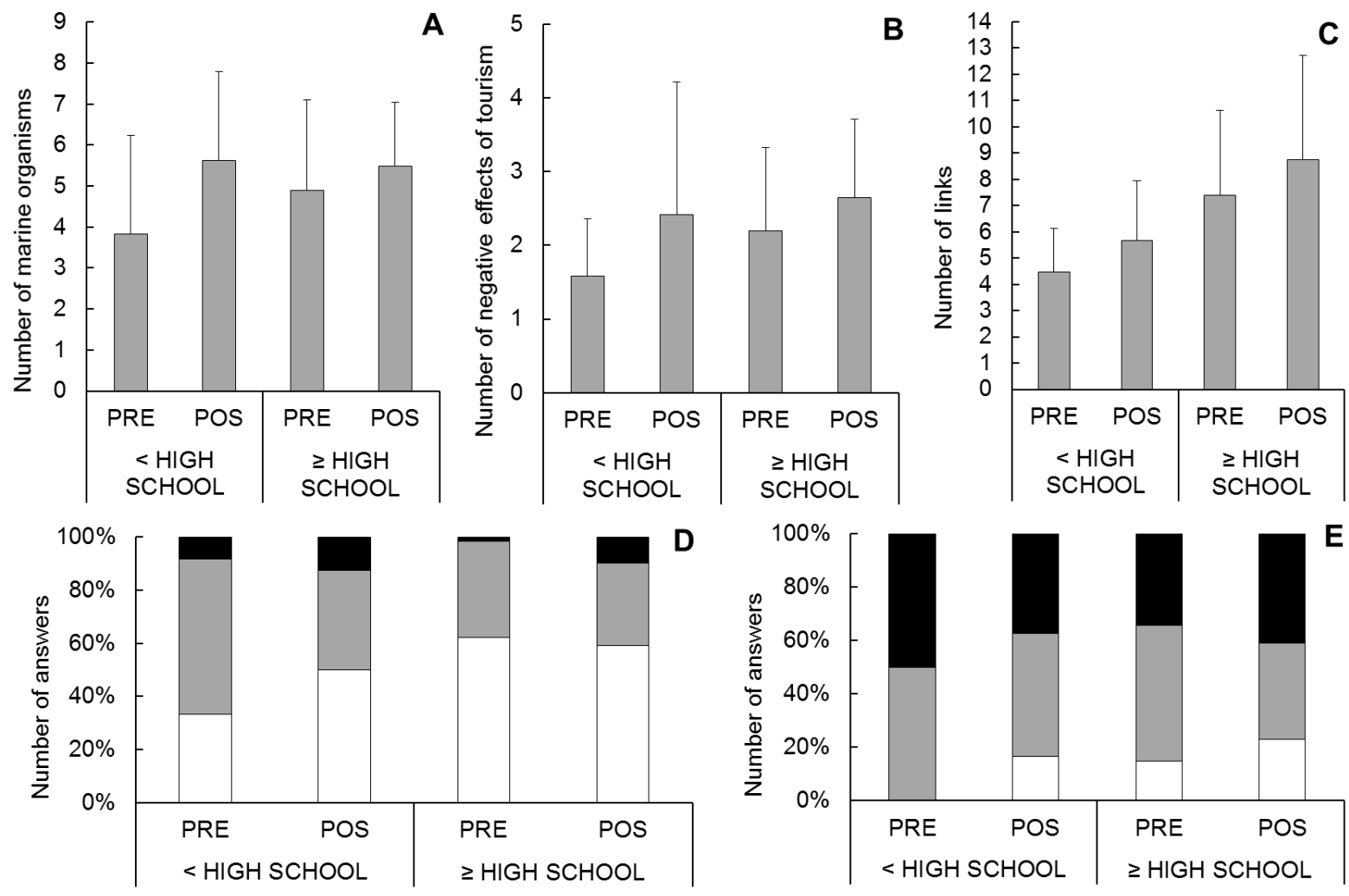

$\square$ SATISFATORY $\square$ UNSATISFATORY $\square$ PARTIALLY

ISATISFATORY $\square$ UNSATISFATORY $\square$ PARTIALLY

Figure 8: Number (mean + standard deviation) of cited marine organisms $(A)$, negative effects of tourism (B) and links in the web of life (C); number (percentage) of satisfactory, unsatisfactory and partially satisfactory answers for the understanding of the importance of macroalgae (D) and marine food chain $(E)$, in the pre and pos test according to scholarship.

Figura 8: Número (média + desvio padrão) de organismos marinhos citados $(A)$, efeitos negativos

do turismo (B) e elos da teia da vida (C); número (percentagem) de respostas satisfatórias, insatisfatórios e parcialmente satisfatórios para a compreensão da importância de macroalgas (D) e da cadeia alimentar marinha $(\mathrm{E})$, no pré e pós teste de acordo com a escolaridade.

\section{Discussion}

This study showed an increase in responses that demonstrate an integrated perception of the environment and the greater knowledge about the evaluated indicators, at the end of the trail. This result shows that the marine trail as an experimental ecotouristic product meets the function specified by Lima (1998) and Lechner (2006). Even the individual factors as age, sex, origin and education had influenced tourist's answers, especially for the level of education. The significant increase in knowledge about marine organisms present in the region, the negative effects of tourism and number of links in the web of life also shown that the ecotouristic product contributed effectively for a change of perceptions and a better sense of awareness, similar to results of Pedrini, Brotto and Messas (2012b).

Forestell (1993) states that the marine ecotourism is the ideal activity for establishing a situation of dynamic imbalance in the practitioner, thus experiencing a new environment, different marine ecotourism practices should emphasize the discrepancies between the initial knowledge of the participants and the new perception arising out of the lived experience. The statements arisen from this work 
were very similar to the ones of Wegner et al. (2004), in João da Cunha Island in Santa Catarina, in similar circumstances.

Overall, the sample members had their environmental awareness significantly influenced by the product with the increase in knowledge about the negative effects of tourism on marine organisms of the region and in their perception of awareness about the components of the marine environment. However, the assimilation and changing of key concepts, as evaluated, proved heterogeneous, according to the intrinsic variables of sample components, as also recorded in Petrosillo et al. (2007).

The best performance after the trail, seen for persons of higher level of education, is related to a better understanding of the impacts of tourism as also the higher number of links in the web of life, indicating greater awareness and concern for the environment. Inglehart (1997) suggests that this concern is more common from people of higher level of education who can afford such "post materialists" values.

The results from Petrosillo et al. (op cit), at marine protected areas have also shown that the concern for the environment is significantly associated with higher levels of education. Nevertheless, for these tourists, the product does not contributed to the increase in concern about the environment, as indicated by no significant increases after the trail.

Brechin and Kempton (1994), argue that the concern for the environment can be similar between people from different origins. In this study, the similarity in the results obtained for tourists coming from the inland or from the coast are evidenced. Although apparently, tourists coming from the coast have been more affected by the trail, as evidenced by the significant increase in knowledge about the importance of macro-algae and marine food chain.

The ethical issue involving different forms of environmental awareness handled by Buckley (2005), apparently permeates the unconscious and ideals of those who depend on and seek forms of recreation in the nature. The above stated was evidenced not only by the collected data, but also by the upheaval attitudes and feelings aroused on beach goers at João Fernandes beach in the face of the traditional capture of live bait for tuna boats by seine nets dragged over the reef ecosystems, as perceived during the project surveys. Although this work presented different aspects of marine environmental perception, its results are similar to those of Machado et al $(2009,2010)$. Who found greater knowledge about reef organisms for respondents above 50 years of age, as this work achieved similar results for better comprehension about the web of life for tourists elder than 40 years.

In the study of Arnocky and Stroink (2011) it was stated that there are differences between the genders when it comes to altruistic attitudes about the environment, this could explain the better performance recorded from female tourists. In general, the here presented results suggest that the most susceptible tourists for a change of mind, are the middle-aged women, somehow a kind of Shirley Valentine's effect, as here named, similarly to Ryan (2002), that stated something similar for the generic tourism. However questionable is the power of the ecotourism experience on changing their way of living profoundly and significantly, although the valuable hints upraised to develop new approaches and techniques to better evaluate the influences of the genre on EE projects. 
Evaluating the increase in environmental awareness among tourism professionals, Pedrini et al (2012) have not noted significant influence of variables such as age, sex, level of education and origin; however, at the present study it was found that these influences occur in tourists. This assumption could be valuable for tourism entrepreneurs and employees, as it evidence that intrinsic factors, may influence their understanding about the environment and the implications of touristic activities, as suggested by Rodger and Moore (2004).

Studies of Bertuol (2005) in Santa Catarina-Brazil and Rangel et al (2013) in Algarve - Portugal, stated that guided underwater trails are a way for increasing the awareness of tourists, these achievements strengthen the potential of underwater trails in protected areas as a sustainable economic activity, coupled to emancipatory environmental education, bringing social, environmental and economic benefits.

\section{Final considerations}

Even though the enormous potential for conservational projects by aims of marine ecotourism in the Brazilian coast, the efforts made for this are still incipient, as even nowadays the touristic activities at a so prominent destination as Armação dos Búzios are majorly undertaken in massive, clumsy, exclusionary and predatory ways (PEDRINI et al., 2011).

The Ecoturismar Project (Marine Ecotourism in Marine Protected Areas) developed an experimental ecotourism product in order to offer society a viable alternative to be undertaken replacing the above highlighted touristic activities. Otherwise, local touristic appeal as the human community and the marine landscape will surely lose its unique character, additionally, marine organisms, as corals, sponges, fish, turtles, etc. will disappear from the region, stirring seriously the artisanal fishery as also diving and sun and sea tourism business.

Thus, the present study demonstrated that the marine ecotourism through underwater trail in protected areas is surely a sustainable alternative that must be undertaken integrated with environmental education activities, bringing environmental, social and economic benefits for customers and traditional communities that embrace this practice replacing unsustainable activities.

The Ecotourismar Project developed an experimental ecotourism product in order to make available a sustainable alternative for the touristic trade. Replacing massive and excluding forms of touristic products presently developed in MPAAB. Thus, the present study has shown that Transformative and Emancipatory Environmental education by marine ecotourism through underwater trail in a protected area is a viable alternative for sustainable marine tourism. It presents socioeconomic sustainability to the receiving community, replacing socially exclusive activities as currently performed in the marine tourism in the region.

\section{References}

ARNOCKY, S.; STROINK, M.L. Gender differences in environmental concern and cooperation: The mediating role of emotional empathy. Current Research in Social Psychology, v. 16, n. 9, p. 1-14, 2011. 
AYROSA, C.R. Trilhas subaquáticas guiadas: uma alternativa sustentável para a conservação do ambiente marinho. Estudo de caso da llha do Campeche, Florianópolis/SC. In: CONGRESSO DE ECOLOGIA DO BRASIL,10., Anais....: São Lourenço, Brasil, SEB, 16-22 de setembro de 2011, p.1-2.

BARDIN, L. Análise de conteúdo. Lisboa: Edições 70, 1995.

BARBOSA, A.G.P.; PERINOTTO, A.R.C. Trilha Ecológica do Cavalo-Marinho; Ecoturismo em Barra Grande, Pi. Revista do Programa de Pós-Graduação em Turismo, Caxias do Sul, v. 1, n.1, p. 45-55, 2010.

BARBOSA, K.C. Turismo em Armação dos Búzios (RJ, Brasil): Percepções locais sobre os problemas da cidade e diretrizes prioritárias de apoio a gestão ambiental. 2003. 124 f. Dissertação (Mestrado em Ciência Ambiental), Universidade Federal Fluminense, Niterói, 2003.

BAUDE, J.L.; BLOUET. S.; GRANDRIVE. R.D.DL.; JOURDAN E.; PIANTE. C. Underwater Trails Handbook. Marseille: MedPAN North Project/WWF France, 2012, $\quad 80 \quad$ p.; $\quad$ disponível em: http://ecorem.fr/reseaumer/wakka.php?wiki=GuidesTechniques/download\&file=Und erwater trail handbook.pdf; acesso em: 30/01/2015

BERCHEZ, F., CARVALHAL, F.; ROBIM, M. J. Underwater interpretative trail guidance in improve education and decrease ecological damage. International Journal of Environment and Sustainable Development, Genebra, v. 4, n.2, p. 128139, 2005.2 Disponível em: http://www.inderscience.com/info/inarticle.php?artid=7235; acesso em: 20/10/2015.

BERCHEZ, F.; GHILARDI, N.; ROBIM, M.J.; PEDRINI, A.G.; HADEL, V.F.; FLUKIGER, G.; SIMÕES, M.; MAZZARO, R.; KLAUSENER, C.; SANCHES, C.; BESPALEC, P. Projeto trilha Subaquática - Sugestão de diretrizes para a criação de modelos de Educação Ambiental para ecossistemas marinhos. OLAM -Ciência e Tecnologia-, Rio Claro (SP), v. 7, n. 3, p. 181-208, 2007; disponível em: http://www.periodicos.rc.biblioteca.unesp.br/index.php/olam/article/view/901; acesso em: 01/07/2011.

BERTUOL, P.R.K., Efeitos de atividades de Mergulho Autônomo sobre um ambiente de Costão Rochoso. 2005. Dissertação (Mestrado em Ciências e Tecnologia Ambiental). Universidade do Vale do Itajaí, Centro de Ciências Tecnológicas, da Terra e do Mar, Itajaí, 2005.

BRASIL, Ministério do Turismo. Ecoturismo: visitar para conservar e desenvolver a Amazônia. Brasília: MMA/SCA/PROECOTUR, 2002, 52 p.

BRASIL, Ministério do Turismo. Plano Nacional de Áreas Protegidas. MMA, Secretaria de Biodiversidade e Florestas, Departamento de Áreas Protegidas. Brasília: MMA, 2006a.

BRASIL, Ministério do Turismo. Diretrizes para Visitação em Unidades de Conservação. MMA, Secretaria de Biodiversidade e Florestas, Departamento de Áreas Protegidas. Brasília: MMA, 2006b.

BRASIL, Ministério do Turismo. Programa de Regionalização do Turismo Roteiros do Brasil - Introdução à Regionalização do Turismo. Brasília: Ministério do Turismo, 2007. Disponível em http://www.turismo.gov.br.; acesso em: $12 / 03 / 2015$. 
BRASIL, Ministério do Turismo. Programa Turismo nos Parques. MMA, Instituto Chico Mendes de Conservação da Biodiversidade, Ministério do Turismo e EMBRATUR. Brasília, 2008. Disponível em http://www.turismo.gov.br.; acesso em: $12 / 03 / 2015$.

BRASIL, Ministério do Turismo. Dinâmica e Diversidade do Turismo de Base Comunitária: desafio para a formulação de política pública. Brasília: Ministério do Turismo, 2010a. Disponível em http://www.turismo.gov.br.; acesso em: $12 / 03 / 2015$.

BRASIL, Ministério do Turismo. Perfil do Turista de Aventura e do Ecoturista no Brasil. Ministério do Turismo \& ABETA. São Paulo: ABETA, 2010b. 96 p.

BRASIL, Ministério do Turismo Ecoturismo: orientações básicas. Ministério do Turismo, Secretaria Nacional de Políticas de Turismo, Departamento de Estruturação, Articulação e Ordenamento Turístico, Coordenação Geral de Segmentação. 2. ed. Brasília: Ministério do Turismo, 2010c, 90 p. Disponível em http://www.turismo.gov.br.; acesso em: 12/03/2015.

BRECHIN S. Objective problems, subjective values, and global environmentalism: evaluating the postmaterialist argument and challenging a new explanation. Social Science Quarterly, n. 80, p. 793-811, 1999.

BRECHIN, S. R; KEMPTON, W. Global environmentalism: A challenge to the postmaterialism thesis? Social Science Quarterly, v. 75, p. 245-269, 1994.

BUCKLEY, R. In search of the narwhal: ethical dilemmas in ecotourism. Journal of Ecotourism, v. 4, 129-134, 2005.

CATER, E. Between the Devil and the Deep Blue Sea: Dilemmas for marine Ecotourism. In: GARROD, B; WILSON, J. (Edit.) Marine Ecotourism: issues and Experiences. Clevendon: Channel View, 2003, p. 37-47.

CASTRO, C. B. Coral Vivo comemora 2 anos de patrocínio pelo Programa Petrobrás Ambiental. Projeto Coral Vivo Notícias, n. 7, p. 2, jan/março de 2009.

FENNEL, D. Ecoturismo. Londres: Routledge, 1999.

FORESTELL, P. H. If Leviathan has a Face, Does Gaia Have a Soul?: Incorporating Environmental Education in Marine Eco-tourism Programs. Ocean \& Coastal Management, v. 20, p. 267-282, 1993.

FREIRE, P. Pedagogia da autonomia: saberes necessários à prática educativa. 25aㅡ. Ed. São Paulo: Paz e Terra, 1996.

GARROD, B., WILSON J.C. Nature on the Edge? Marine Ecotourism in Peripheral Coastal Areas. Journal of Sustainable Tourism, v.12, p.95-120, 2004.

GARROD, B.; WILSON, J.C.; BRUCE, D.M. Ecoturismo Marino Genuinamente Sostenible en el Área Atlântica de La UE: Guia de Buenas Prácticas. Bristol: University of the Weast of England, 2002, 1-82 p.

GARROD, B., WILSON, J. C., BRUCE, D. M. Defining Marine Ecotourism: A Delphi Study. In: GARROD, B; WILSON, J. (Edit.) Marine Ecotourism: issues and Experiences. Clevendon: Channel View, 2003, p.17-36. 
HADEL, V. F. Programa de Visitas ao Centro de Biologia Marinha-USP: o monitor na mediação entre a Academia e o grande público. In: PEDRINI, A.G. (Org.) Educação Ambiental Marinha e Costeira no Brasil. Rio de Janeiro: Eduerj, 2010, p. 93-114.

HANNAK, J. S. A snorkel trail based on reef condition and visitor perception as a management tool for a threatened shallow water reef in Dahab (South Sinai, Egypt). Tese (Magistra der Naturwissenschaften), Universität Wien, 2008, 54 p; disponível em: $\quad$ http://othes.univie.ac.at/2273/1/2008-11-03 9502823.pdf;acesso em: $30 / 11 / 2015$.

INGLEHART, R. Modernization and Postmodernization: Cultural, Economic, and Political Change in 43 Societies. Princeton: Princeton University Press; 1997.

LECHNER, L. Planejamento, implantação e manejo de trilhas em unidades de conservação. Cadernos de Conservação, Curitiba, v. 3, p. 1-123, 2006.

LIMA, M.L.C. (Eco) turismo em unidades de conservação. In: RODRIGUES, A.B. (Org.). Ecoturismo no Brasil: possibilidades e limites. São Paulo: Contexto, 2003, p. 71-87.

LIMA, M.L.P.; SCHMIDT, A.; CHAMAS, C.C.; WEGNER, E. Implantação de Trilhas Subaquáticas Guiadas na llha do Campeche, Florianópolis-Sc. In: ENCONTRO NACIONAL DE GERENCIAMENTO COSTEIRO, 1., Anais...,Florianópolis, Agência Brasileira de Gerenciamento Costeiro, 2006, 4 p.

LIMA. S. Trilhas interpretativas: a aventura de conhecer a paisagem. Caderno Paisagem, Paisagens, Rio Claro (UNESP), n. 3, p. 39-44, 1998.(CD ROM)

LIMA, M.L.P.; SCHMIDT, A.; DIDOMENICO, M. Implantação de trilhas subaquáticas guiadas em Picinguaba, Ubatuba, SP. In: CONGRESSO BRASILEIRO DE OCEANOGRAFIA, 3., Anais..., 17-21 de maio de 2010, Rio Grande (RS), AOCEANO, p. 32-34.

MACHADO, G.E.M.; NASSAR, C.A.G.; PEDRINI, A.G. Implantação de Trilhas Subaquáticas para uso em Educação Ambiental nas Unidades de Conservação. In: PEDRINI, A.G. (Org.) Educação Ambiental Marinha e Costeira no Brasil. Rio de Janeiro: EdUERJ, 2010, p.33-50.

MADIN, E.M.P.; FENTON, D.M. Environmental Interpretation in the Great Barrier Reef Marine Park: An Assessment of Programme Effectiveness. Journal of Sustainable Tourism, v. 12, n. 2, p.121-137, 2004; disponível em: http://www.tandfonline.com/doi/abs/10.1080/09669580408667228; acesso em: 30/11/2015.

MARASCHIN. C.M.A.; PEDRINI, A.G. A educação ambiental no ecoturismo: um estudo de caso numa empresa de ecoturismo no Rio de Janeiro, RJ, Brasil. Resultados preliminares. In: ENCONTRO DE EDUCAÇÃO AMBIENTAL DO ESTADO DO RIO DE JANEIRO, 7., Anais..., 23-25 de setembro de 2003, p. 353362.

MEIRELES, C. P.; RIBEIRO, F. de V.; ANDRADE, A. C. de; FERREIRA, Y. C. da S.; CREED, J. C. Implantação da primeira trilha interpretativa terrestre e subaquática em área de proteção ambiental na llha Grande (Angra dos Reis, RJ). In: CONGRESSO NACIONAL DE PLANEJAMENTO E MANEJO DE TRILHAS, 2., Anais..., 16-18 de outubro de 2013, Universidade do Estado do Rio de Janeiro, Rio de Janeiro, p. 76. 
MENDONÇA, R.; NEIMAN, Z. O Ecoturismo no Brasil. São Paulo: Manole, 2005, $291 \mathrm{p}$.

MUNICÍPIO DE ARMAÇÃO DE BÚZIOS. Decreto Municipal no 135, de 6 de novembro de 2009.

OIGMAN-PSZCZOL, S. S.; CREED, J. C. Quantification and Classification of Marine Litter on Beaches along Armação de Búzios, Rio de Janeiro, Brazil. Journal of Coastal Research, v. 23, n. 2, p. 421-428, 2007.

OLIVEIRA, W.L.; BRASILEIRO, I.LG.; KESSELRING, E.L.B.; FRANÇA, O.E. Ecoturismo- Melhores práticas para gestão de sistemas de trilhas em propriedades rurais no Centro Oeste. In: JUNQUEIRA, V.; NEIMAN, Z. (Org.) Educação Ambiental e Conservação da Biodiversidade. Barueri (SP): Manole, 2007, p. 187218.

ORAMS, M. Marine Ecotourism in New Zealand: An Overview of the Industry and its management. In: GARROD, B; WILSON, J. (Edit.) Marine Ecotourism: issues and Experiences. Clevendon: Channel View, 2003, p. 234-248.

PEDRINI, A.G. Avaliação da Educação Ambiental no Ecoturismo (com Trilhas): uma Proposta Metodológica de Qualidade Conceitual. OLAM - Ciência e Tecnologia -, Rio Claro (SP), v. 7, n.2, p. 83-106, dez/2006.

PEDRINI, A.G. A Educação Ambiental no Ecoturismo; passado e futuro. In: SEABRA, G. (Org.) Turismo de Base Local: identidade cultural e desenvolvimento regional. João Pessoa: Ed. Universidade Federal da Paraíba, 2007a, p. 249-260.

PEDRINI, A.G. Ecoturismo, Interpretação e Educação Ambientais; condensando conceitos. In: CONGRESSO NACIONAL DE ECOTURISMO, 6,. Anais..., 8-11 de novembro de 2007b, $12 \mathrm{p}$.

PEDRINI, A.G. Avaliação da educação ambiental empresarial brasileira: uma metodologia para identificar sua qualidade. In: PEDRINI, A.G. (Org.) Educação Ambiental Empresarial no Brasil. São Carlos: RiMa, p. 3-15, 2008.

PEDRINI, A.G. Trilhas Marinhas: uma síntese para a Educação Ambiental In: CONGRESSO NACIONAL DE PLANEJAMENTO E MANEJO DE TRILHAS, 2., Anais...,Outubro de 2013, Universidade do Estado do Rio de Janeiro, 2013, Rio de Janeiro, v.1, p.1 - 20; disponível em: http://infotrilhas.com/anais IICNPMT/6IICNPMT anais GT\%2006.pdf; acesso em: 24/04/2015.

PEDRINI, A.G.; DE-PAULA, J. C. Educação Ambiental: Críticas e Propostas. In: PEDRINI, A.G. (Org.) Educação Ambiental: Reflexões e Práticas Contemporâneas. 6 ed. Petrópolis: Vozes, 2008, p. 88-104.

PEDRINI, A. G.; ANDRADE-COSTA, E.; SILVA, V.G.; PINA, R.S.; SABA, M.; BERCHEZ, F. Projeto EcoTurisMar: Uma Proposta de Educação/Interpretação Ambiental para o Ecoturismo Marinho em Áreas Protegidas. Estudo de Caso Preliminar no Parque Estadual da llha Anchieta, São Paulo, Brasil. In: SEMANA NACIONAL DE OCEANOGRAFIA, 21., Anais..., 2-8 de agosto de 2009, Belém, Aoceano.

PEDRINI, A.G.; BEHRENDS, E.; MORAES, A.A.J.; MESSAS, T.P. Flora bentônica da trilha marinha entre as Praias de João Fernandes/João Fernandinho, Área de Proteção Ambiental Marinha de Armação de Búzios, Estado do Rio de Janeiro, 
Brasil. In: CONGRESSO BRASILEIRO DE FICOLOGIA, 14., Anais..., maio de 2012, Universidade Federal da Paraíba, João Pessoa, 2012.

PEDRINI, A.G.; BROTTO, D.S.; GHILARDI-LOPES, N.P.; LOPES, M.C.; FERREIRA, L.P. Environmental education and ecotourism concepts in Marine Protected Area of Armação de Búzios, Rio de Janeiro, Brazil: reflections for the adoption of coastal ecotourism. Revista Brasileira de Ecoturismo, São Paulo, v.8, n. 1, p. 59-73, fev/abr, 2015; disponível em: http://www.sbecotur.org.br/rbecotur/seer/index.php/ecoturismo/article/viewFile/838/ 780;acesso em:30/11/2015.

PEDRINI, A.G.; BROTTO, D.S.; LOPES, M.C.; FERREIRA, L.P.; GHILARDI, N.P. Percepções sobre Meio Ambiente e o mar por interessados em Ecoturismo Marinho na Área de Proteção Ambiental Marinha de Armação de Búzios, estado do Rio de Janeiro, RJ, Brasil. Revista Pesquisa em Educação Ambiental, v.8, p. 25-38, 2013; disponível

em: http://www.cienciamao.usp.br/tudo/exibir.php?midia=rev\&cod= revistapesquisaeme ducaca; acesso em: 12/03/2014.

PEDRINI, A.G.; BROTTO, D.S.; LOPES, M.C.; MESSAS, T. Gestão de Áreas Protegidas com Educação Ambiental Emancipatória pelo Ecoturismo Marinho: A Proposta do Projeto Ecoturismar. Olam -Ciencia \& Tecnologia-, Rio Claro (SP), n. 3, especial, p. 6-81, set. 2011. Disponível em: http://www.periodicos.rc.biblioteca.unesp.br/index.php/olam/article/view/4967;

Acesso em: 1 ago. 2011.

PEDRINI A.G.; BROTTO D.S; MESSAS, T.P. Avaliação de Aproveitamento no I Curso de Atualização em EA para o Turismo Marinho e Costeiro (I CEAM). Revista Eletrônica do Mestrado em Educação Ambiental, v. 28, p.133-147, 2012; disponível em: http://www.seer.furg.br/remea/article/view/3110; acesso em: 02/02/2009.

PEDRINI, A.G.; BROTTO, D.S.; PIMENTEL, D.S.; BEHRENDS, E.; SOARES, A.A.J.; LOPES, M.C.; RUA, M.B. Ecoturismar project: Efficacy evaluation of an experimental ecotouristic product at marine Environmental Protection Area of Armação de Búzios (APAMAB), state of Rio de Janeiro - Brazil. In: BIOINC, Arraial do Cabo, Anais..., 2013b, v.1, p.5; disponível em: https://www1.mar.mil.br/ieapm/publicacoes; acesso em: 30.11/2015.

PEDRINI, A.G.; COSTA, C.; SILVA, V.G.; MANESCHY, F.S.; NEWTON, T.; BERCHEZ, F.A.; GHILARD, N.P.; SPELTA, L. Gestão de Áreas Protegidas e Efeitos da Visitação Ecoturística pelo Mergulho com Snorkel: O Caso do Parque Estadual da llha Anchieta (Peia), Estado de São Paulo. Revista Eletrônica do Mestrado em Educação Ambiental (REMEA), Rio Grande, v. 20, p. 1-20, 2008ä; disponível em: http://www.seer.furg.br/remea/article/viewFile/3825/2276; acesso em: 07/04/2014.

PEDRINI, A.G.; DUTRA, D.; ROBIM, M.J.; MARTINS, S.L. Gestão de áreas protegidas e avaliação da educação ambiental no ecoturismo: Estudo de caso com o projeto Trilha subaquática - Educação ambiental nos ecossistemas marinhos - no Parque Estadual da llha Anchieta, Ubatuba, São Paulo, Brasil. OLAM, Ciência e Tecnologia, Rio Claro (SP), v.8, n.2, p. 31-55, 2008b. (CD ROM)

PEDRINI, A.G.; LIMA, L.M.M.; SANTOS, T.V.; NUNES, R.M.; BROTTO, D.S. Percepção Ambiental Pública sobre atitudes e responsabilidades frente às Mudanças Climáticas Globais por frequentadores de uma praça pública na cidade 
do Rio de Janeiro (RJ, Brasil) e o papel das fontes de informação. In; ENAMPPAS, 7., Anais...,17-20 de maio de 2015, 15 p.(Pendrive)

PEDRINI, A.G.; MESSAS, T.P.; PEREIRA, E.S.; GHILARDI-LOPES, N.P.; BERCHEZ, F.A. Educação Ambiental pelo Ecoturismo numa trilha marinha no Parque Estadual da Ilha Anchieta, Ubatuba (SP). Revista Brasileira de Ecoturismo, São Paulo, v.3, n.3, p. 428-459, 2010. Disponível em: file:///C:/Users/Alexandre\%20Pedrini/Downloads/97-522-1-PB.pdf; acesso em: 30/11/2015.

PEDRINI, A.G.; MERIANO, D. Avaliação da Qualidade do Ecoturismo Terrestre no Brasil. Estudo de caso com uma empresa atuante em trilhas, RJ, Brasil. In: CONGRESSO NACIONAL DE ECOTURISMO, 6, Anais..., 8-11 de novembro de 2007, 15 p. (CD ROM).

PEDRINI, A.G.; RHORMENS, M.S.; BROTTO, D.S.; Educação Ambiental Emancipatória pelo Ecoturismo Marinho de Base Comunitária; uma Proposta Metodológica com Sustentabilidade Socioambiental. In: ARAUJO, M. I. O.; SANTANA, C. G.; NEPOMUCENO, A. O. L. (Org.) Educadores Ambientais: caminhos para a práxis. Aracajú: Criação, 2016, p.47-64.

PETROSILLO, G.; ZURLINI; M. E.; CORLIAN, N.; ZACCARELLI, M.; DADAMO. Tourist perception of recreational environment and management in a marine protected area. Landscape and Urban Planning n. 79, p. 29-37, 2007.

PIRES, P.S. Entendendo o Ecoturismo. In: TRIGO, L.G.G. (Org.) Análises Regionais e Globais do Turismo Brasileiro. São Paulo: Roca, 2005, p.483-494.

RANGEL, M.O; PITA, C.; GONÇALVES, J.M.S.; LEITE, L.; COSTA, C.; ERZINI, K., Ecotourism snorkelling routes at Marinha Beach (Algarve). Journal of Coastal Research, special issue, n. 61, p. 274-281, 2011.

REIGOTA, M. Meio Ambiente e Representação Social. 7 ed. São Paulo: Cortez, 2007, 87 p.

RODGER, K.; MOORE, S. Bringing science to wildlife tourism: the influence of managers' and scientists' perceptions. Journal of Ecotourism, v.3, p.1-19, 2014.

RHORMENS, M.S. Educação Ambiental Emancipatória pelo Ecoturismo Marinho nos ecossistemas recifais na Área de proteção Ambiental de Tinharé/Boipeba, Cairu, Bahia, Brasil. 2013. 167 f. Dissertação (Mestrado em Práticas em Desenvolvimento Sustentável), PROGRAMA DE PÓS-GRADUAÇÃO EM PRÁTICAS EM DESENVOLVIMENTO SUSTENTÁVEL, Universidade Federal Rural do Rio de Janeiro, Rio de Janeiro,2014.

RHORMENS, M.; PEDRINI, A.G.; Educação Ambiental Emancipatória pelo Ecoturismo Marinho de base Comunitária nos Ecossistemas Recifais da Área de Proteção Ambiental das Ilhas de Tinharé e Boipeba, município de Cairu, Bahia, Brasil. In: CONGRESSO INTERNACIONAL DE EDUCAÇÃO AMBIENTAL DOS PAÍSES E COMUNIDADES DA LÍNGUA PORTUGUESA, 3., Anais..., 7 a 11 de julho de 2015, Torreiras, Portugal.

RHORMENS, M.; PEDRINI, A.G.; GHILARDI-LOPES, N.P. Implementation Feasibility of a Marine Ecotourism Product on the Reef Environments of the Marine Protected Areas of Tinharé and Boipeba Islands, (Cairu, Bahia, Brazil). Submetido. 
RYAN, C. The tourist experience. Tourism Management, v. 25, p. 139-147, 2004. SALES, E.J.C.G.; ANTONIO FILHO, F.D. Turismo e a problemática da inclusão/exclusão socioespacial: um estudo exploratório em Armação de Búzios RJ. In: SIMPÓSIO DE PÓS-GRADUAÇÃO EM GEOGRAFIA DO ESTADO DO SÃO PAULO (SIMPGEO), 1., Anais..., 17-19 de outubro de 2008, Rio Claro (SP), UNESP, p. 1122-1140. (CD ROM)

SAITO, C.H.; FIGUEIREDO, J.; VARGAS, I.A.; Educação Ambiental Freiriana no contexto de formação de educadores ambientais. In: PEDRINI, A.G., SAITO, C.H. (Org.) Paradigmas Metodológicos em Educação Ambiental. Petrópolis: Vozes, 2014, p. 71-81.

SÃO PAULO. Passaporte para as trilhas de São Paulo. São Paulo: Secretaria do Meio Ambiente, 2008, 104 p.

SECRETARIA MUNICIPAL DE TURISMO E CULTURA DE ARMAÇÃO DE BÚZIOS (Setuc.buzios@gmail.com). Dados estatísticos;. E.mail em 09.05.2011,1p.

TOSUN, C. Limits to community participation in the tourism development process in developing countries. Tourism Management, Amsterdan, n. 21, p. 613-633, 2000; disponível em: http://yoksis.bilkent.edu.tr/doi getpdf/articles/10.1016-S02615177(00)00009-1.pdf; acesso em: 30/11/2015.

TUNALA, P.L. Impactos Negativos de Banhistas e de Mergulhadores com Snorkel na Praia de João Fernandes, Área de Proteção Ambiental Marinha de Armação dos Búzios, Rio de Janeiro, Brasil. Monografia (Bacharelado em Ciências Biológicas), Universidade Estadual do Norte Fluminense, Campos, 2013.

TUNALA, P.L.; BITTAR, V.T.; PEDRINI, A.G. Efeitos Ambientais Negativos de Mergulhadores em Apnéia (com 'Snorkel') na Praia de João Fernandes, Área de Proteção Ambiental Marinha de Armação dos Búzios, Rio de Janeiro, Brasil. In: CONGRESSO DE ECOLOGIA DO BRASIL, 6., Anais..., outubro de 2013, 2 p.(CDROM)

VEAL, A.J. Metodologia de Pesquisa em lazer e turismo. São Paulo: Aleph, 2011, $542 \mathrm{p}$.

WEGNER, E. Proposta metodológica para implantação de trilhas subaquáticas na Ilha de Porto Belo, Porto Belo, SC. 2002. 86 f. Dissertação (Mestrado em Turismo e Hotelaria), Universidade do Vale do Itajaí, Itajaí, 2002.

WEGNER, E.; TONIOLI, F.C.; CABRAL, D.Q. Underwater trails: a new possibility of marine tourism. Journal of Coastal Research, Lawrence, n. 39, 2004.

\section{Acknowledgments}

Here we include the main persons who directly supported us in this research project of Environmental Education for Marine Ecotourism, which lasted about five years and received no funding from finance agencies. Mrs. Beatriz Martins from Ville La Plage/La Foret guesthouse for granted stays and continuous encouragement to our project. To Dr. Adriana Saad, Colonel Lyrio Filho and Marcela Palermo. To friends of Joao Fernandinho pub. The staff of the Department of Extension Subreitoria Extension and Culture of UERJ, especially Nadia, Ana Paula, Paulo and Daniela for the financial viability and the great affection with which accepted the challenge of promoting the I Course on Environmental Education for the Marine Coastal Tourism. 
Trainees of LAFEA for the field help. To Prof. Dra. Gisele Hadju, from the Genetics Department of IBRAG/UERJ, for the determination of porifers. The fellow of the rectory Juzeler Silva for their help in getting UERJ vehicle at the beginning of our activities, to Rodolfo Gutterres Giordano, for teaching about safety at sea and 1st aid in the occasion of the II CEAM, Rosana Mendonça Nunes accompanying always with great love and is co-author of our work. The Regional Council of Biology-RJ/ES for the aid received for the acquisition of diving equipment. To Yara Shimada Brotto, for language revision of the manuscript. To the Faculty of Oceanography, Geography Institute and Roberto Alcântara Gomes Biology Institute for support to the I CEAM.

Alexandre de Gusmão Pedrini: Universidade do Estado do Rio de Janeiro, Rio de Janeiro, RJ, Brasil.

E-mail: pedrini@globo.com

Link para o currículo Lattes: http://lattes.cnpq.br/6918956483557789

Daniel Shimada Brotto: Universidade do Estado do Rio de Janeiro, Rio de Janeiro, RJ,

Brasil.

E-mail: danshima63@gmail.com

Link para o currículo Lattes: http://lattes.cnpq.br/2478406351234148

Douglas de Souza Pimentel: Universidade do Estado do Rio de Janeiro/Universidade Federal Fluminense, Rio de Janeiro, RJ, Brasil.

E-Mail: douglasgeia@gmail.com

Link para o currículo Lattes: http://lattes.cnpq.br/9374128914372886

Eric Behrends: Universidade Santa Úrsula, Rio de Janeiro, RJ, Brasil,

E-Mail: the.erick@hotmail.com

Link para o currículo Lattes: http://lattes.cnpq.br/0759858559744079

Alenne Alves Junqueira de Moraes: Universidade do Estado do Rio de Janeiro, Rio de Janeiro, RJ, Brasil.

E-Mail: alennejunqueira@gmail.com

Link para o currículo Lattes: http://lattes.cnpq.br/0071261175891345

Data de submissão: 17 de fevereiro de 2016

Data de recebimento de correções: 16 de agosto de 2016

Data do aceite: 16 de agosto de 2016

Avaliado anonimamente 